\title{
Milli Mücadele Döneminde Fener Rum Patrikhanesi'nin ve Metropolitlerin Pontus Rum Devleti Kurulmasına Yönelik Girişimleri
}

\author{
Yrd. Doç Dr. Mehmet OKUR*
}

ÖZET

Karadeniz kıyılarında bir Pontus Rum Devleti'nin kurulması fikrinin açıkça ifade edilmesi, Filik-i Eterya'nın kurulması ve Yunanistan'ın bağımsızlığını kazanmasıyla başlar. Zira Karadeniz Bölgesi'nde Pontus adıyla bir devlet kurmak, Megalo İdea'nın hedeflerinden biri olarak ortaya konulmuştu. Bu hedefe ulaşmak için harekete geçen Filik-i Eterya Cemiyeti, Yunanistan ve Fener Rum Patrikhanesi'nden aldığı destekle Osmanlı topraklarında yaşayan Rumlar arasında propaganda faaliyetlerine başladı.

Balkan Savaşlarına kadar gizli yürütülen Pontusçu girişimler I. Dünya Savaşı yıllarında hem siyasi hem de çete faaliyetleri yönünden iyice belirginleşmişti. Bölgedeki çetecilik hareketi Rusya Hükümeti ve Rusya'daki Yunan siyasi memurlarının girişimiyle bir silahlı ayaklanmaya dönüştürülmeye çalışıldı. Hatta bu amaçla Batum'da teşkil edilen gizli komitelerle bölgeye silah, cephane ve mühimmat gönderildi.

I. Dünya Savaşı'ndan Osmanlı Devleti'nin mağlup olarak çıkması ise Rumlar açısından yeni bir dönemin başlangıcı oldu. Zira 30 Ekim 1918'de imzalanan Mondros Mütarekesi, Müttefiklere, çıkarlarının tehlikede olduğu her yerde duruma müdahale etmek hakkını veriyordu (7.madde). Bu hüküm, Rum Cemiyetlerinin, Fener Rum Patrikhanesi'nin ve diğer metropolitlerin, müttefiklerin müdahale etmelerini sağlamak ve nihayetinde Pontus Rum Devleti'ni kurmak için Hiristiyan nüfusu harekete geçirmelerine fazlastyla yeterli oldu.

Gerçekten de İstanbul'daki Pontus Rum teşkilatlarlyla, Fener Rum Patrikhanesi, mütarekeden hemen sonra Pontus meselesini alevlendirmeye çalışmışlar ve Karadeniz Bölgesi'nde ihtilal hareketlerinin genişleyip gelişmesine

\footnotetext{
- Atatürk Üniversitesi, Bayburt Eğitim Fakültesi Öğretim Üyesi.
} 
yardımcı olmuşlardır. Hatta bazı patrikler Rum teşkilatlarının başında ya da içerisinde yer almışlardır.

Pontus Rum Devleti kurulmasına yönelik faaliyetlerde; Rum cemiyetleri ve Fener Rum Patrikhanesi'nden başka, Trabzon Metropoliti Hrisantos, Samsun Metropoliti Germanos, Niksar Metropoliti Polikarpos ve Zile Piskoposu Eftimos Zitos da büyük gayret sarfetmekteydi.

\title{
ABSTRACT
}

\section{The Activities of Patriarchate and Metropolitans Towords To}

\section{Establishment of Pontus Greece State During National Struggle}

The idea of the establishment of Pontus Greece State in Black Sea Region started with the establishment of Filik-i Eterya an the accomplishment of Greece's independent. Because the establishing the state in Black Sea Region was one of the aims of Megalo İdea named as Pontus. Starting action to accomplish this aim Filik-i Eterya Society started propaganda activities toward to Greeces living in Otoman State taking support from Greece and Patriarchate.

The idea of the establishment of Pontus Greece State took to revolt phase during Balkan War while this consideration was the sole idea until this war. During the World War I, the Pontus activities were prominent as to political and armed band activities. After this war, the Patriarchate and Pontus Greece societies in Istanbul set in a blaze the pontus problem. These activities assisted the rising up the revolting activities in Black Sea Region.

Key Words: Patriarchate Metropolitan Pontus Black Sea Region State

\begin{abstract}
"Azınlıklara gelince, bu konuda değiş-tokuş ileri sürmüşü̈k öbür devletlerin temsilcileri de bizim fikrimizi izlemişler ve onaylamışlardı. Ama bir fesat ve hıyanet ocă̆ı olan, ülkede ayrilık ve uyuşmazlık tohumları saçan Hristiyan hemşehrilerimizin huzur ve refahı içinde uğursuzluk ve felaket simgesi olan Rum patrikhanesi'ni artık topraklarımızda barındıramayız. Bu tehlikeli örgütü ülkemizde tutmamız için ne gibi vesile ve nedenler ileri sürülebilir? Türkiye'nin Rum Patrikhanesi için topraklarında bir sı̆̆ınak göstermeye ne zorunluluğu vardır? Bu fesat yuvasının gerçek yeri Yunanistan değil midir?'
\end{abstract}

Mustafa Kemal Atatürk

'Lozan Konferansı görüşmelerinin yapıldığı sırada Mustafa Kemal Paşa'nın, Le Journal Muhabiri Paul Herriot'ya Çankaya'da verdiği demeç. Atatürk'ün Söylev ve Demeçleri III, Ankara, 1997, s. 79. 
I. Dünya Savaşı'ndan Osmanlı Devleti'nin mağlup olarak çıkması Pontus Rum Devleti hayali peşinde koşanlar açısından yeni bir dönemin başlangıcı oldu. Zira 30 Ekim 1918'de imzalanan Mondros Mütarekesi, müttefiklere çıkarlarının tehlikede olduğu her yerde duruma müdahale etme hakkını veriyordu (7. Madde). Bu hüküm, Rum cemiyetlerinin, Fener Rum Patrikhanesi'nin ve metropolitlerin, müttefiklerin müdahale etmelerini sağlamak üzere Hristiyan nüfusu harekete geçirmeleri için fazlasıyla yeterli oldu.

Mütarekeden hemen sonra harekete geçen Rum cemiyetleri, hem Karadeniz'deki Rum nüfusunu artırmak hem de asayişi ihlal edip İtilaf Devletleri'nin müdahalesini sağlamak için bölgeye göçmen ve çete mensubu taşımaya başladılar. Rum cemiyetlerinin Karadeniz'e göçmen getirmesinde onlara en çok yardım eden kurumların başında Fener Rum Patrikhanesi gelmekteydi. ${ }^{2}$ Zira Patrikhane, bir kaç kez Osmanlı Hükümeti nezdinde girişimde bulunarak Rumların eski topraklarına dönmelerine izin verilmesini istemişti. ${ }^{3}$

Fener Rum Patrikhanesi hem mütarekeden önce hem de mütarekeden sonra başta siyasi faaliyetler olmak üzere, çetelerin teşkilatlanması, desteklenmesi, gösterilerin düzenlenmesi, kültürel faaliyetlerin yürütülmesi gibi Türkiye'deki bütün Rum faaliyetlerini kontrol eden bir kuruluş konumundaydı. Hatta Fener Rum Patrikhanesi, Rumların meselelerini Avrupa Devletleri hükümetlerine kamuoylarına ve Türkiye'deki temsilcilerine iletmek üzere komisyon dahi teşkil etmişti. ${ }^{4}$ Yine Fener Rum Patrikhanesi, hemen bütün siyasi faaliyetlerinde Yunanistan hükümeti ile işbirliği yapmış ve Yunanistan'dan, Rusya'dan ve Amerika'dan çok sayıda Rum muhacirin Türkiye'ye yerleştirilmesini sağlamıştır.

Polis Müdir-i umumisinin 16 Haziran 1919 tarihli raporuna göre, Yunan Hükümeti'nin İstanbul'daki temsilcileri, Patrikhane ve Kordos Cemiyeti vasıtasıyla Osmanlı memleketlerindeki Rumları teşkilatlandırmak, çeteler teşkil etmek ve asayişi bozmak maksadıyla muhacir kaydetmekte ve Anadolu'ya sevketmekteydiler. ${ }^{6}$

İstanbul Fener Rum Patrikhanesi ile Yunan Hükümeti arasındaki işbirliğini ve amaçlarını en iyi ortaya koyan belge, Rumların 1919 yılının sonlarına doğru yapılan seçimlere katılmalarına izin vermeyen

\footnotetext{
${ }^{2}$ İbrahim Ethem Atnur, Tehcirden Dönen Rum ve Ermenilerin İskânı Meselesi (Yayınlanmamış Yüksek Lisans Tezi), Erzurum, 1991, s. 116.

${ }^{3}$ Sabah, 15 Ağustos 1334/1918. Bu sırada Osmanlı Hükümeti başta Trabzon olmak üzere Karadeniz limanlarına gelen Rumların karaya çıkmalarına izin vermeyerek engel olmaya çalışmaktaydı. (BOA, DH-ŞFR, 100/142).

${ }^{4}$ Atnur, Tehcirden Dönen Rum ve Ermenilerin İskânı Meselesi, s. 116.

${ }^{5}$ BOA, DH-KMS, 47-2/42.

${ }^{6}$ BOA, DH-KMS, 47-2/42.
} 
Patrikhane'nin ${ }^{7}$ daha sonra Yunan Sefareti'nin görüş ve talimatları doğrultusunda İstanbul Rumlarından ve Yunanlılardan "İstanbul Mebusları" adı altında kendi vekillerini seçmesidir. Bu konuyla ilgili olarak Mustafa Kemal Paşa'nın 8 Kasım 1919'da Harbiye Nazırı Cemal Paşa'ya gönderdiği raporda şu bilgiler verilmektedir: ${ }^{8}$

"Harbiye Nazırı Cemal Paşa Hazretleri'ne Mevrut Şifredir,

"1- Geçen ay kiliseden idare heyeti seçimi yapılmış ve birçok Yunanlı idare heyeti azalığına seçilmiştir.

“2- Rum Patrikhanesi Yunan Sefareti'nden aldığı emir üzerine kilise mütevellilerinden başka, kırk kişilik bir heyet seçtirmiş ve bunlara, İstanbul meselesi barış konferansında gündeme gelirse; Yunanistan, Fransa, İngiltere ve İsviçre nezdinde girişimlerde bulunarak, bütün Rumlar namına İstanbul'un ilhakını talep ve hiç olmazsa beynelmilel bir idareye kavuşturmak hakkında girişimlerde bulunmak ve çeşitli yelerden Osmanlı ülkesine sevk olunması kararlaştırılan çetelerin icap eden yerlere ulaştırılmasını sağlamak görevini vermiştir.

"3- Yunanlı Miralay Aleksandros, on iki gün evvel buraya gelerek Sefarethanede Yunan Hafiye Zabıtası'nın İstanbul teşkilatına memur olmuş ve işe başlamıştır. Vazifesi bitince Atina'ya gidecektir. Bu kişinin bir kaymakam, iki yüzbaşı, iki mülazim muavini vardır. Bu muavinlerden Yüzbaşı Dirikis Kolokilas, bu günlerde bir torpido ile Pontus Hükümet-i Cumhuriyesi'nin jandarma teşkilatını tensik etmek üzere Trabzon cihetlerine hareket edecektir."

Mustafa Kemal Paşa endişelerinde haklıydı. Zira bu durum, Patrikhane'nin Mart 1919'da Osmanlı Devleti'ne bağlılığını kopardıktan sonra bağımsızlık için attığı önemli bir adımdı. Dahası, bu Rum milletvekillerinin sayısı, Avrupa'da, İstanbul'da Rum nüfusunun çok olduğuna dair bir izlenim yaratacaktı.

Fener Rum Patrikhanesi'nin ilgilendiği en önemli konulardan birisi de Pontus meselesiydi ve bu hususta Pontus Rum Teşkilatlarını etkili bir şekilde desteklemişlerdi. Hatta bazı patrikler bu teşkilatların başında ya da içerisinde yer almışlardı. ${ }^{10}$ Nitekim Mavr-i Mira cemiyeti'nin başkanı Fener Rum Patriği'nin yardımcısı Dorotheos'tu. ${ }^{11}$

${ }^{7}$ Bülent Atalay, Fener Rum Patrikhanesi'nin Siyasi Faaliyetleri (1908-1923), İstanbul, 2001, s. 120.

${ }^{8}$ H.T.V.D, Yıl: 4, (Mart 1995), Sayı: 11, Ves. No: 256.

${ }^{9}$ Atalay, Fener Rum Patrikhanesi'nin Siyasi Faaliyetleri, s. 120.

${ }^{10}$ M. Süreyya Sahin, Fener Patrikhanesi ve Türkiye, İstanbul, 1996, s. 236.

${ }^{11}$ Atnur, Tehcirden Dönen Rum ve Ermenilerin İskânı Meselesi, s. 121. 
Patrikhane, Pontus faaliyetlerini yakından takip etmek üzere düzenli olarak iki haftada bir çeşitli şahısları Karadeniz Bölgesi'ne gönderiyordu. Bunlar genellikle Patrikhane'de görevli olanlar veya ruhanilerin yakın akrabalarıydı. Böylece Patrikhane hem gizliliği muhafaza hem de güvenilir bilgiler elde ediyordu. En son Batı Karadeniz'deki Pontus faaliyetlerini yönlendirmek ve genel durum hakkında incelemeler yapmak üzere Kadıköy Metropolithanesi'nde görevli Sinoplu Piskopos Kosti'nin oğlu Mihail ve Diyakos Neofilos'un oğlu görevlendirilmişti. ${ }^{12}$

Yine Türkiye'ye yönelik faaliyetlerden cesaret alan Fener Rum Patrikhanesi, Anadolu'daki bütün Metropolitlere birer yazı göndererek Türkler aleyhinde, İtilaf Devletleri temsilcilerine şikayette bulunmalarını ve Yüksek Komiserliklere telgraflar çekmeleri emrini vermişti. ${ }^{13}$

Ankara Valiliği'nden Dahiliye Nezareti'ne gönderilen 3 Temmuz 1919 tarihli telgrafta, İstanbul Fener Rum Patrikhanesi tarafından Yozgat'in Akdağmadeni Kazası Rumları adına Keskin Metropoliti Papa Eftim ${ }^{14}$ ve Ankara'da Vasil'e gönderilen talimatlara yer verilmekteydi. Bu talimatlarda "Çeteciliğe fevkalade önem verilmesi, asayişin ihlaline çalışılması ve daima İslamlar ve hükümet aleyhinde şikayette bulunmaları tavsiye edildiği ve hangi mahallin şikayeti çok ve asayişi kötü olursa oraların hemen Yunan askeri tarafından işgal edileceği ve Trabzon'un Yunan askeri ve İtilaf Kuvvetleriyle işgal olunup, daha sonra Yunanistan'a ve Ankara'nın ve Maden civarının da Trabzon'a ilhak olunacağı" bildirilmekteydi. ${ }^{15}$

İstanbul Fener Rum Patrikhanesi'nin bu talimatı üzerine Karadeniz Bölgesi'ndeki ve Anadolu'nun diğer bölgelerindeki birçok Metropolit Türklerin Hristiyanlara zulmettiği iddiasında bulunmaya, hükümete ve İtilaf Devletleri Yüksek Komiserlerine telgraflar çekmeye, asılsız iddialar ileri sürmeye başladılar. Samsun Metropoliti'nin köylerine dönmekte olan on iki

\footnotetext{
${ }^{12}$ Atalay, Fener Rum Patrikhanesi'nin Siyasi Faaliyetleri, s. 148.

${ }^{13}$ BOA, DH-KMS, 47-2/42.

${ }^{14}$ Papa Eftim, 1300 (1884-1885) yılında Ankara Vilayeti Yozgat Sancağı Akdağmadeni
} Kasabası İstanbulluoğlu Mahallesi'nde doğmuştur. Asıl ismi Pavli olan Eftim, Ankara'da ticaretle uğraşmaktan başka din eğitimi de almış ve 1918'de Keskin Metropolit Vekili olmuştur. O dönemde Anadolu'da ve İstanbul'da yaşanan gelişmeleri yakından takip eden Papa Eftim, Fener Rum Patrikhanesi'nin karşısında yer almış (Yonca Anzerlioğlu, Türkiye'de Ortodoks Türkler, Basılmamış Doktora Tezi, Ankara, 2002, s. 201-202), buradan gelen ve Hristiyanların Türklere karşı harekete geçirilmesini isteyen talimatları uygulamadığı gibi özellikle Orta Anadolu'daki Ortodoks Türklerle temasa geçerek onları milli mücadeleye destek olmaya çağırdı. Büyük Taarruz'dan hemen sonra da Bağımsız Türk Ortodoks Patrikhanesi'nin kurulmasını sağladı. Mustafa Kemal'in; "milli mücadelede bize bir ordu kadar hizmet etti” dediği Papa Eftim, 14 Mart 1918'de İstanbul'da öldü. (Melek Fırat, "Yunanistan'la İlişkiler", Türk Dış Politikası I, Kurtuluş Savaşı'ndan Bugüne Olgular, Belgeler, Yorumlar (Editör: Baskın Oran), İstanbul, 2002, s. 190).

${ }^{15}$ BOA, DH-KMS, 49-2/42. 
Rum'un yolda soyulduğunu şikayet eden telgraf, ${ }^{16}$ Gümüşhane merkezinden Metropolit İkatumus imzasıyla gönderilen Torul Kazası'nın köylerini eşkıyanın bastığına dair raporu, ${ }^{17}$ Bartın'da Kürt Sait, Çakırbey Oğlu İsmail Paşa, İzmirli Hüseyin, Varnalı Hacı Mustafá ve Eyüboğlu Ahmet'in Hrıstiyanları tehdit etmekte olduklarına dair Fener Rum Patrikhanesi'nin yazısı, ${ }^{18}$ Yine Fener Rum Patrikhanesi'nin, Trabzon ve Konya'da Hıristiyanların Müslümanlarca katledildiğine dair başvurusu, ${ }^{19}$ Samsun'un Çarşamba Kazası'nın Kurşunlu tarafındaki bir karyesinde bir papazın, kızının ve oğlunun Türk çeteleri tarafından kaçırıldığı hakkındaki şikayeti, ${ }^{20}$ Kastamonu Vilayeti'nde Ermeniler aleyhine bir galeyan mevcut bulunduğu ile ilgili Ermeni Patrikhanesi'nin Dahiliye Nezareti'ne yazısı ${ }^{21}$ ve yine Ermeni Patrikhanesi'nin, Boğazlıyan'a bağlı Menteşe Köyü Ermenilerine Türk çetelerinin taarruz ve tecavüzde bulunduklarını ileri sürmesi $i^{22}$ bu asılsız iddialardan yalnızca bir kaçını oluşturmaktadır. Ancak, hükümet her iddiayı büyük bir ciddiyetle dikkate almasına, araştırılması için ilgili vilayet ve mutasarrıflıklara emirler göndermesine ve bu emirler üzerine yapılan araştırmalara rağmen bu haberler doğrulanamamıştı. ${ }^{23}$

Patrikhane'nin ve metropolitlerin bu tür ihbar ve şikayetlerinin birden bire artması dikkat çekici bir durumdu. Zira Osmanlı Devleti'nin azınlıklara karş1 çağdaşı olan devletlere oranla daha hoşgörülü olduğu bilinen bir gerçekti. Nitekim Venizelos Kabinesi'nde Hariciye Nazırı olan Politis, bu gerçeği şöyle ifade etmişti. "İstanbul ve havalisinde Yunanlılığın menafi-i maddiye ve maneviyesi emsalsiz bir mevki işgal etmektedir. Üç yüz bin Osmanlı Rum, ellibin Yunan teb'ası, patriklik makarrı, muhtelif müessesat, çok miktarda kiliseler, mektepler, umur-u hayriyeye müteallik asar vb. Türk himayesinin bahşeylediği himayeyi ve bunlara Türk idaresinin temin eylediği menafi-i hiçbir idare temin edemez." ${ }^{24}$

Anadolu'ya müdahale etmede bahane arayan İtilaf Komiserleri, bu telgraflar üzerine Hükümete verdikleri notalarda, "Rumlar hakkında bir katliam icrası için İslam ahalinin memurlar tarafından silahlandırıldıkları, böyle bir hal vukua gelecek olursa büyük küçük bütün memurların mes'ul tutulacakları" ifade edilmekteydi. ${ }^{25}$

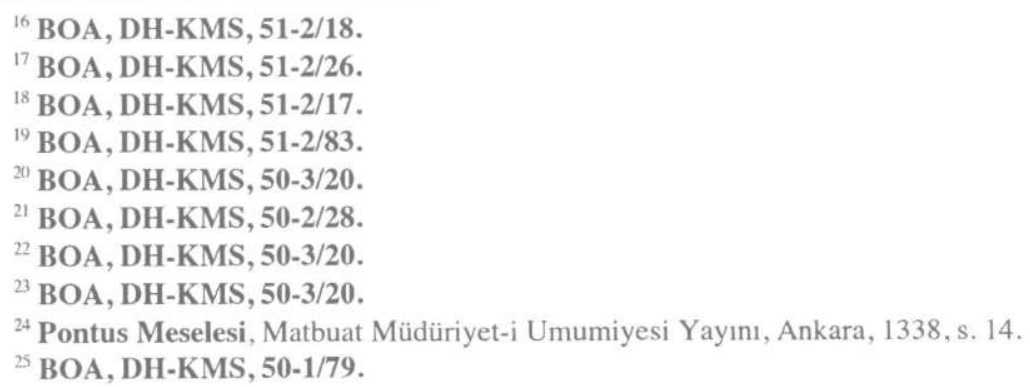


İtilaf Yüksek Komiserlerinin bu notaları üzerine endişelenen hükümet, bütün vilayetlere ve mutasarrıflıklara gönderdiği talimatta, Hristiyanlara yönelik herhangi bir baskının olmaması için gerekli önlemlerin alınmasını, Müslümanları Hristiyanlara karşı harekete geçmeye sevk edenlerin derhal tutuklanmasını, Rumlardan bir saldırı vukua geldiğinde ise ahalinin müdahalesine katiyen meydan verilmemesini istedi. ${ }^{26}$

Vilayetlerden gelen cevabi yazılarda Rumlara ya da Ermenilere yönelik Böyle bir fikir hissedilmediği, herhangi bir olay vuku bulmadığı ve ahalinin silahlandırılmadığı belirtilmiştir. Samsun Mutasarrıfı Ethem Bey tarafından 5 Nisan 1919'da hükümete gönderilen yazıda, Hristiyanlara zulmedildiği yönündeki iddiaların hemen her yerde olduğu gibi İtilaf Devletleri'nin nazar1 dikkatlerini çekmek ve Rumların da müdafaaya davet ile hükümeti bir kat daha sıkıntıya sokmak maksadıyla yayılan şayialardan ibaret olduğu" bildirilmekteydi. Aynı telgrafla, Rumların iddialarının aksine, Rum çetelerinin Türklere karşı tecavüzlerini artırdıkları, buna karşılık kendilerinin Türkleri teşvik etmek yerine sabırlı olmaya davet ettikleri de ifade edilmekteydi. ${ }^{27}$ Aynı tarihte Trabzon Vali Vekili'nden gönderilen telgrafta da iddialar reddedilmiş ve herkesin işiyle gücüyle meşgul olduğu bildirilmiştir. ${ }^{28}$

Fener Rum Patrikhanesi'nin bir diğer önemli faaliyeti de Bolşevik ihtilalinden sonra İstanbul'a kaçan Ruslardan silah satın alması ve bunları Rum çetelerine göndermesiydi. ${ }^{29}$ Patrikhane adeta silah ve mühimmat deposu haline gelmişti. Türkçe gazetelerde çıkan haberler üzerine Fransız ve İtalyan askerleri tarafından Patrikhanede arama yapılmış ve çok sayıda tüfek, makineli tüfek ve mühimmata el konulmuşsa da Patrikhane'nin imdadına İngilizler yetişmiş ve el konulan silahlar İzmit'te Yunan askerlerine teslim edilmiştir. ${ }^{30}$

Patrikhane, depolarını savaş için gerekli silah ve savaş malzemeleri ile doldurduğu gibi, para yönünden de iç ve dış yardımlarla fevkalade takviye ediyorlardı. Bu hususu Venizelos şöyle ifade etmekteydi.

“Fener Rum Patrikhanesi'nden bir heyet gelerek beni gördü. Karadeniz sahillerinde müstakil bir Rum devleti kurmak üzere harekete geçmek için sadece Yunan zabitlerini beklemekte olduklarını bana ibla ğ etti. Heyetin sahip oldukları serveti öğrenince miktarı beni hayrete bıraktı. Kendilerinin sahip olduğu altının mevcudu, o an Yunan Hükümeti'nin sahip olduğu altın

\footnotetext{
${ }^{26}$ BOA, DH-KMS, 50-1/79.

${ }^{27}$ BOA, DH-KMS, 50-1/179.

${ }^{28}$ BOA, DH-KMS, 50-1/79.

${ }^{29}$ ATASE, İSH, K.652, G.55, B.55-1.

${ }^{30}$ Atalay, Fener Rum Patrikhanesi'nin Siyasi Faaliyetleri, s. 131.
} 
yekûnundan fazla idi. Bir taraftan da bilhassa Amerika'dan ve dünyanın her tarafındaki Rumlardan mühim miktarda yardım görüyorlardı., ${ }^{, 31}$

Fener Rum Patrikhanesi, Pontus meselesi ile uğraşmak üzere Batum eşraf ve tüccarlarından Bünyadoğlu'nun yardımı ile bir cemiyet de teşkil etmişti. Cemiyetin ilk üyeleri; Trabzon, Amasya, Samsun ve Kayseri metropolitleriydi. Sonradan üyeler çoğaldığı gibi, Yunanistan, İngiltere, Fransa ve Amerika Birleşik Devletleri'ne heyetler gönderilerek oralarda da şube açılması sağlanmıştır. Bu cemiyet, yayın faaliyetlerini Yunan Konsolosu Kozis'in yaptığı "Serbest Pontus" adında bir de gazete yayınlamaya başlamıștı. Aynı cemiyet Kafkasya'da yaşayan Rumlardan yaklaşık on bir bin kadarının Karadeniz kıyılarına göçünü de sağlamıştı. ${ }^{32}$

Yine Patrikhane, "Pontus Cumhuriyeti" adiyla kurulacak "Yeni Yunanistan"ın sinırlarını belirleyen bir de harita bastırarak Anadolu'da bulunan bütün metropoliklerine gönderdi. Haritada yeni Cumhuriyet, merkezi Samsun olmak üzere Batum'un kuzeyinden İnebolu'nun batısına kadar Karadeniz kıyılarıyla Lazistan, Trabzon, Ordu, Samsun, Sinop, Kastamonu, Ankara, Yozgat, Sivas, Gümüşhane, Şarkikarahisar, Tokat, Amasya ve Çorum illeriyle, kısmen Erzincan'ı içine alıyordu. ${ }^{33}$

Pontusçuların Osmanlı Devleti üzerinde en faal çalıştıkları merkez Trabzon, en faal kişisi ise Trabzon Rum Metropoliti Hrisantos idi. Gümülcine'de doğan, ihtilalci yetiştirmekle meşhur Heybeliada Ruhban Okulu'ndan mezun olan ve Avrupa'da dört yıl eğitim gören Hrisantos, ${ }^{34}$ kardeşleri Antaş ve Yorgi'yi de birer Pontusçu olarak yetiştirmişti. Antaş Yunan ordusunda üst düzey subaylığa kadar yükseldi. Yorgi de önce Selanik, sonra da Kafkasya'da Pontus gönüllü alaylarında görevlendirildi. ${ }^{35}$

Birinci Dünya Savaşı'nda Rusların Trabzon'u işgalleri esnasında, onların oluşturduğu idare heyetinde yer alan Hrisantos, ${ }^{36}$ şimdi de İngilizlerin desteğini sağlamak için gayret sarfediyordu. Avrupa başkentlerinde, Pontus meselesine ilişkin kesin bir cevap veya söz alamamasına karşın, bunu Rumlara açıkça ifade etmek yerine Trabzon'a çok yakında bir Rum Vali'nin atanacağını Hıristiyanların hukukunun korunması

\footnotetext{
${ }^{31}$ Şahin, Fener Patrikhanesi ve Türkiye, s. 238.

${ }^{32}$ Şahin, Fener Patrikhanesi ve Türkiye, s. 236.

${ }^{33}$ Şahin, Fener Patrikhanesi ve Türkiye, s. 237-238.

${ }^{34}$ Pontus Meselesi I. Kısım, s. 19; Dimitri Kitsikis, Yunan Propagandası, İstanbul,

${ }^{35}$ Atalay, Fener Rum Patrikhanesi'nin Siyasi Faaliyetleri, s. 93-94.

${ }^{36}$ Hrisantos, Trabzon'un Ruslar tarafından işgali esnasında, başta kendisi olmak üzere Rumlara gösterdiği ilgiden dolayı Rus Çarı'na teşekkür etmişti. (Sabahattin Özel, Milli Mücadelede Trabzon, Ankara, 1991, s. 6; Yerasimos, "Pontus Meselesi", Toplum Bilim, Sayı: 43/44, (Güz. 1988), (Kış 1989), s. 54). Ayrıca Hrisantos, Trabzon'a giren Ruslardan temin ettiği silahları, Türklere karşı kullanmaları için çetelere vermiş ve bundan sonra çete faaliyetleri önemli ölçüde artmıştı. (Yerasimos, Pontus Meselesi, s. 40).
} 1964 , s.334 
için, İtilaf Devletleri'nin barış antlaşmasına kendilerini ilgilendirecek birçok madde ekleyeceklerini, bunun Paris Konferansı'nın bir vaadi olduğunu beyan ediyordu. ${ }^{37}$

Hrisantos'un bu şekilde propaganda yapmasının çeşitli nedenleri vardı. Bunlardan birincisi, Osmanlı sınırları içerisindeki Rumların Pontus meselesine sahip çıkmalarını sağlamak, başka bir deyişle, Pontus meselesine İtilaf Devletleri'nin tam destek verdiklerini ileri sürerek, bağımsız bir Pontus Devleti kurulacağı yönünde Rumlar arasındaki inancı canlı tutmaktı. Diğeri ise başta Batum olmak üzere Kafkas Vilayetlerinde bulunup da, Anadolu'ya göç etmekte tereddüt gösteren Rumlara, korkulacak bir şey olmadığını göstermek, onların Anadolu'ya girmeleri durumunda İtilaf Devletleri'nin güvencesi altında olacaklarına inandırmaktı.

Hrisantos, Pontus Meselesi hakkında Avrupa devletleri başkentleri nezdinde yaptığı girişimlerden beklediği sonucu alamayınca ve Anadolu'daki milli hareketin giderek güçlenmesi karşısında politika değiştirerek Türk-Rum ortaklığına ilişkin şaşırtıcı açıklamalarda bulunmaya başladı. Hrisantos, Paris Barış Konferansı dönüşünde yaptığı açıklamalarında; Avrupa'da, Trabzon'da bir Ermeni idaresinin kurulmaması için çalıştığını, Paris'teki Ermeni heyetiyle yaptığ1 görüşmelerde onlara, Trabzon ve çevresinde Türk ve Rum unsurunun çoğunlukta olduğunu, bu bakımdan Türklerle Rumların birlikte yaşamaları gerektiğini ifade ettiğini söyledi. Hrisantos, Trabzon Mevki Kumandanlığı'nı ziyaretinde de O'na "biz çalı̧̧mazsak Avrupalılar bizi çiftlik edinmek istiyorlar, elele vererek müttehiden çalışırsak memleket düzelir. Avrupa efkârı entrika, fesat ve münafıkla meşbudur. Anadolumuz gibi saf ve temiz değildir." demiş ve son zamanlarda Trabzon ve civarındaki asayişten dolayı medyun-u şükran kaldığını ilave etmiştir. ${ }^{38}$ Hrisantos bu sözleriyle, Ermeni isteklerini ön plana çıkararak, Rum emellerini gizlemeye, dolayısıyla Türklerin güvenini kazanmaya çalışmaktaydı.

Hrisantos'un bu açıklamalarında samimi olmadığı Paris Konferansı dönüşü önce İstanbul'da sonra da Batum ve Tiflis'deki faaliyetlerinden anlaşılmaktadır. Zira Hrisantos, bu faaliyetleriyle müstakil Pontus Rum Devleti fikrinden vazgeçmediğini göstermişti ${ }^{39}$ Paris Konferansı sonrasında Patrikhane'de Hrisantos'un da katıldığı bir toplantı düzenlendi. Bu toplantıda Pontusçuluk konusunda yapılan son girişimler ve bölgedeki Rumların ihtiyaçlarını belirlemek üzere Trabzon'a giden heyetin hazırladığı bir rapor ele alındı. Bu raporda Pontus faaliyetleri için Yunanistan'dan ve Rusya'dan yardım geldiği belirtilmekte ve bunun devam etmesi gerektiği

\footnotetext{
${ }^{37}$ ATASE, İSH, K.201, G.143, B.143-1,2.

${ }^{38}$ H.T.V.D, Y1l: 4, (Mart 1955), Sayı: 11, Ves. No: 276.

${ }^{39}$ Mesut Çapa, Pontus Meselesi, Trabzon ve Giresun'da Milli Mücadele, Ankara, 1993, s. 33.
} 
üzerinde durulmaktayd $1 .{ }^{40}$ Hrisantos, Batum ve Tiflis ziyaretinde ise buradaki Rumlarla temas kurmaktan başka Yunanistan'dan aldığı talimat doğrultusunda Gürcistan'la Osmanlı Devleti aleyhine bir dostluk ve ittifak antlaşması yapmaya çalıştı. Zira Rum ve Ermeni işbirliğinin Trabzon meselesi yüzünden uygulamaya sokulamaması üzerine gerek Yunan Hükümeti ve gerek Rum cemiyetleri Gürcistan'la işbirliği yapmayı kendi menfaatlerine daha uygun buluyorlardı. Bu işbirliğini engelleyecek herhangi bir durum da sözkonusu değildi. ${ }^{41}$ Nitekim, 16 Kasım 1919'da Harbiye Nezareti'nden XV. Kolordu Kumandanlığı'na gönderilen telgrafta bu durum vurgulanarak, Trabzon Metropoliti'nin Pontus Rum Devleti kurmak için girişimlerde bulunmaya devam ettiğini bu hususta hariçten Rumların desteğini temin veyahut vilayet içindeki Rumlar arasında easlı bir teşkilat yapmak için çalıştığı, harekâtının uygun bir surette takip edilmesi gerektiği ifade edilmekteydi. ${ }^{42}$ XV. Kolordu Kumandanı Kâzım Karabekir Paşa tarafından Harbiye Nezareti'ne gönderilen raporda ise Hrisantos'un Batum'daki Pontus Komitesi'nde yaptığı konuşmada, Avrupa'da çok iyi ilgi gördügüunden ve Pontus davası için aldığı destekten bahsettiği bildirilmekteydi. ${ }^{43}$

Trabzon Rum Metropoliti Hrisantos faaliyetlerini Batum'da sürdürürken, Venizelos'ta Yunan Ordusu subaylarından Albay Katenyodis'i Pontus Rumlarını askeri birlikler halinde teşkilatlandırmak için Batum ve Tiflis'e göndermişti. ${ }^{44}$

Hrisantos'un çabaları sonucunda Batum'da Pontus Meselesi için önemli adımlar atıldı. 19 Temmuz 1920'de Kafkasya ve Güney Rusya temsilcilerinin katıldığı Pontus Kongresi toplandı. Bu kongrede Hrisantos da bulunmaktaydı. Kongrede; Rumların eğitim amacıyla Yunanistan'a gönderilmeleri ve Avrupa'dan, Rusya'dan ve Yunanistan'dan Türkiye'ye gelen Rumların durumu görüşüldü. ${ }^{45}$

Hrisantos'un faaliyet alanlarından biri de Karadeniz'e yönelik Rum göçmenlerine karşı Osmanlı makamlarında oluşmaya başlayan tepkiyi azaltmak, mümkün olursa ortadan kaldırmaktı. Yukarıda bahsedildiği üzere Avrupa dönüşünde Trabzon'da verdiği beyanat ve "Müslüman Hemşehrilerime Açık Mektup" adlı beyannamenin bir amacı da buydu. Zira Osmanlı makamları Karadeniz'e dönen göçmenlerin çoğunluğunun savaş sırasında bölgeden ayrılanlar olmadığını, aksine Yunan Hükümeti ve cemiyetler eliyle bölgenin asayişini ortadan kaldırmayı amaçlayan çeteler olduğunu söylüyorlardı.

4) Atalay, Fener Rum Patrikhanesi'nin Siyasi Faaliyetleri, s. 149.

${ }^{41}$ ATASE, ISH, K.100, G. 19, B. 19-1.

${ }^{42}$ Ali Güler, Dünden Bugüne Yunan - Rum Terörü, Ankara, 1999, s. 45.

${ }^{43}$ H.T.V.D, Y1l: 4, (Mart 1955), Sayı: 11, Ves. No: 278.

${ }^{44}$ Özel, Milli Mücadelede Trabzon, s. 136.

${ }^{45}$ Íkdam, 20 Temmuz 1336/1920. 
Hrisantos'un faaliyetlerini sadece siyasi olarak nitelemekte yanlış olur. Zira kendisi Avrupa'ya yaptı̆̆ 1 seyahatlerde İtilaf Devletleri Hükümetleri'nin ve kamuoyunu etkilemeye çalışırken ve Batum'da Gürcü ve Ermenilerle ittifak arayışlarını sürdürürken, liderliğini yaptı̆̆ 1 "Pontus İlhak ve İstiklal Komitesi" ile de Trabzon ve çevresine devam etmekte olan Rum göçünü organize ediyordu ${ }^{46}$ Çünkü Rumlar, Samsun'a göre Trabzon'da Türklere oranla daha azdı ve muhtelif hükümetler tarafından yapılan istatistiklerde Trabzon'daki Rum Nüfusu \% 20'den fazla olmadığı ortaya çıkmıştı. ${ }^{47}$ Hrisantos, Osmanlı Hükümetleri'nin 50 yıldan beri Rumları hicret ettirdiklerini, bunların dönmesi durumunda bölgede çoğunluğun ellerine geçeceğini iddia ediyordu. Kafkaslardaki Rumlar arasıda da aynı yönde propaganda yaparak ve bolca paralar harcayarak onları ikna etmeye çalışıyordu. Hatta bu bölgedeki Rumların bir kısmını Trabzon'a getirmeyi de başarmışt. ${ }^{48}$

Yine Hrisantos, Anadolu'daki diğer metropolitlerle düzenli olarak haberleşmekte, onlardan Pontus faaliyetleri için para yardımı da sağlamaktaydı. Nitekim, Ankara Metropoliti, Hrisantos'a yazdığ mektubunda, Rum nüfusunu artırmak için getirilen Rum göçmenlerin sevki faaliyetlerine yardım için şimdilik 2000 Lira para gönderdiğini bildirmişti. ${ }^{49}$

Pontus davası için faaliyet gösteren metropolitlerden biri de Maçka Metropolitiydi ki kendisi Venizelos aleyhtarı ve Hrisantos'un en etkin muhaliflerinden biriydi. İşe, yöresinde yoğun bir teşkilatlanma faaliyetiyle başladı. Maçka'ya bağlı Hamsiköy'den 90 kişiyi etrafına toplayan metropolit, daha iyi çalışabilmeleri için bölgede yardım dağıtan Amerikan Yardım Heyeti'nden kendilerine destek olmalarını istedi. Bu talep üzerine Amerken Heyeti tarafından Maçka Metropolitliği'ne o an için 600 lira yardımda bulunuldu. ${ }^{50}$

Pontusçu faaliyetlerde bulunan bir başka metropolit, Giresun Metropoliti Lavrendios du. Lavrendios, mütarekeden önce devlete sadık bir din adamı görüntüsü vermekteydi. Fakat daha sonra Osmanlı Devleti'nin karşı karşıya kaldığı kötü durumdan Patrikhane'nin emirleri doğrultusunda çalışmaya başladı. ${ }^{51}$ Lavrendios, Giresun ve çevresindeki Rum çetelerin

${ }^{46}$ Hatta bu komite, Rum çetelerine gerekli olan silah ve cephanesinde gizli olarak bölgeye sokulmasını ve depolanmasını sağlıyordu. Bu komitenin, depolarında, göçmen adı altında getirdiği çete mensuplarına dağıtmak üzere 35.000 seri ateşli Rus tüfeği, 20.000'e yakın rovelver, bomba vesaire yanıcı ve patlayıcı madde vardı. (BOA, DH-ŞFR, 102/88; Metin Ayışığı, "Mütareke Başlangıcında Karadeniz Bölgesi'ndeki Rum Tahriklerine Karşı İstanbul Hükümeti’nin Aldığı önlemler”, Milli Mücadele'de Giresun Sempozyumu 6-7 Mart 1999, İstanbul, 1999, s. 61.

${ }^{47}$ BOA, DH-KMS, 53-2/92.

${ }^{48}$ BOA, DH-KMS, 53-2/92.

${ }^{49}$ Pontus Meselesi, Kısım I, s. 46; Özel, Milli Mücadelede Trabzon, s. 137.

${ }^{50}$ ATASE, ísH, K.396, G.2, B.2-1.

${ }^{5 t}$ Atalay, Fener Rum Patrikhanesi'nin Siyasi Faaliyetleri, s. 154. 
ihtiyaçlarını karşılamakta, limana gelen İngiliz ve Yunan gemilerine giderek bölgedeki genel durum hakkında onları bilgilendirmekteydi. ${ }^{52}$ Giresun'da açıkça Yunan propagandası yapan Lavrendios, Giresun Mektebi'ne Yunan bayrağı asmış ve burayı Yunan Salib-i Ahmeri'nin emrine vermişti. Yunanistan'dan veya diğer yerlerden yardım adı altında getirilen silahlar burada toplanmakta ve gerekli görüldüğünde Rum çetelere dağıtılmaktaydı ı. ${ }^{53}$

Pontus Rum Devleti'nin kurulması yolunda en çok çalışanlardan biri de Mondros Mütarekesi'nden hemen sonra Samsun'u Yunan bayraklarıyla donatan Yermanos'tu.$^{54}$ Hrisantos, Avrupa Devletleri nezdinde girişimlerde bulunurken, Yermanos, daha çok Müslümanlara yönelik çete faaliyetlerini organize etmekteydi. Nitekim 1919 yılının Nisan ayında yermanos ve ona bağlı olan Zile Piskoposu Eftimos, çete şeflerini Samsun Piskoposluğu'nda toplayarak, Samsun, Bafra, Çarşamba, Ünye, Fatsa, Tokat, Niksar, Merzifon, Havza, Erbaa, Ladik, Amasya ve Vezirköprü bölgelerinde örgütlenme kararı aldilar. ${ }^{55}$

Yermanos Pontus çetelerini kullanarak hem Türklere zulmediyor, hem de kendilerinin suçsuz oldukları propagandasını yapıyordu. ${ }^{56}$ Bunda başarılı da olmuştu. Çünkü başta İngilizler olmak üzere İtilaf Devletleri'nin baskılarıyla Osmanlı Hükümeti bölgede asayişi sağlamak üzere Mustafa Kemal Paşa'yı görevlendirmek durumunda kaldı.

Metropolit Yermanos, Patrikhane ve müttefikler için casusluk faaliyetleri de yapmaktaydı. Samsun Limanı'na yanaşan Yunan Ioannina gemisiyle, Giresun, Trabzon, Batum ve Sohum'u ziyaret eden Yermanos, buralardaki Rumların durumları hakkında Patrikhane'ye ve Yunan temsilcilerine bilgi vermişti. ${ }^{57}$ Özellikle Mustafa Kemal Paşa'nın Samsun ve çevresindeki faaliyetlerini kendisine bağlı papazların yardımıyla çok yakından takip eden Yermanos, elde ettiği bilgileri Patrikhane'ye ve müttefik temsilcilerine aktarıyordu. Yermanos, Mustafa Kemal Paşa'nın Havza'da büyük bir kalabalığa hitap ettiğini ve onları teşkilatlandırmaya teşvik ettiğine dair bilgileri Havza Papazı'ndan almış ve İngiliz Yüzbaşı Hurst'a iletmişti. $^{58}$

Bundan başka Yermanos, Samsun ve çevresindeki köylerde yaşayan Rumların ellerinde bulunan fazla silahları toplayarak Samsun'da depolar oluşturmakta, daha sonra bu silahları ihtiyaç duydukları zaman Pontus

${ }^{52}$ Mesut Çapa, "Giresun Mutasarrıfı'nın Pontus Meselesi İle İlgili Bir Raporu”, B.T.T.D, (Temmuz- 1987), Sayı: 29, s. 54-58.

${ }^{53}$ BOA, DH-KMS, 53-1/21.

${ }^{54}$ Atalay, Fener Rum Patrikhanesi'nin Siyasi Faaliyetleri, s. 151.

${ }^{55}$ Stefanos Yerasimos, Milliyetler ve Sinırlar (Çev.: Şirirn Tekeli), İstanbul, 1995, s. 373.

${ }^{56}$ Atalay, Fener Rum Patrikhanesi'nin Siyasi Faaliyetleri, s. 152.

${ }^{57}$ Yerasimos, Milliyetler ve Sinurlar, s. 373.

${ }^{58}$ Bilal N. Şimşir, İngiliz Belgelerinde Atatürk I, Ankara, 1992, s. 15-16. 
çetelerine vermekteydi. Yine Yerasimos, kiliselerde cemaatten yetimhaneler için topladığı yardım paralarını amacına uygun olarak değil, Pontus çetelerinin ihtiyaçlarını karşılamak için kullanmaktaydı. Samsun ve çevresinde yapılan bir soruşturmada 100 kadar esnaf ve tüccarın metropolit Yermanos aracılı̆̆ıyla Pontus Cemiyeti'ne üye kaydedildikleri ve faal bir şekilde görev yaptıkları ortaya çıkmıştı. Metropolit Yermanos, bu faaliyetlerini Fener Patrikhanesi'nin ve Trabzon Metropoliti Hrisantos'un emir ve planları dahilinde yürütüyordu. ${ }^{59}$ Nitekim Fener Rum Patrikhanesi'nden gelen davet üzerine İstanbul'a giden Samsun Metropolit Yardımcisi ve Zile Piskoposu Eftimos ise Patrikhane ve Yunan resmi makamlarıyla çeşitli temaslarda bulunduktan sonra beraberinde Niksar Metropoliti Polikarpos Efendi olduğu halde Patrikhane'den aldıkları talimat dairesinde Samsun'a dönmüşlerdi. ${ }^{60}$

Fener Patrikhanesi ile metropolitler arasındaki haberleşmeyi bazen biraz önce ifade edildiği gibi doğrudan görüşmeler yoluyla bazen de kurye olarak kullanılan çocuklar vasıtasıyla sağlanıyordu. Bafra'da hareketlerinden şüphelenilen 12 yaşındaki bir Rum kızının üzerinde bulunan evraklarda Pontus faaliyetleri ile ilgili bilgiler yer almaktayd ${ }^{61}$

Trabzon Metropoliti Hrisantos'un faaliyetleri ile Samsun Metropoliti Yermanos'un faaliyetleri gözönüne alındığında Pontus Rum meselesinde iki farklı tutum izlediği göze çarpmaktadır. Samsun Metropoliti daha çok çetecilik olayları ile ilgilenirken ve bu yönde teşkilatlanmalara giderken, Trabzon Metropoliti Hrisantos Pontus meselesini daha çok siyasi yollarla halletmeye çalışıyordu. Esasında Hrisantos'un içinde bulunduğu durum onu bu yöne zorlamaktaydı. Zira 15. Kolordu Kumandanlığı bölgedeki Pontusçu olaylara meydan vermemek için sıkı tedbirler almış, Erzurum Tortum'da bulunan 3. Fırkayı buradan Trabzon'a kaydırmıştı. Kazım Karabekir Paşa'ya göre, dışardan (İngiltere ve Yunanistan tarafından) herhangi bir müdahale olmadığ 1 taktirde bu tedbirler bölge dahilindeki Rum çetelerini susturmaya yeterliydi. $^{62}$ Bundan başka, Trabzon'daki Rum faaliyetlerine destek verebilecek Samsun'daki gibi herhangi bir İngiliz kuvveti mevcut değildi. Gerçi, sürekli olarak Trabzon Limanı'na İngiliz donanmasına ait savaş gemileri gelip gitmekte ve arada bir şehre asker çıkarmakta iseler de sürekli varlıkları söz konusu değildi. Dolayısıyla Trabzon'daki Pontus faaliyetleri çeteler eliyle değil, siyasi yollarla yürütülmeye çalışılıyordu. Ancak bu durum Trabzon ve çevresinde hiç de Pontus Rum çetesi yoktu demek değildi. Özellikle İzmir'in işgalinden sonra, Rum Cemiyetleri'nin de yardımıyla çok sayıda Rum çetesinin teşkil edilmiş ve Türk köylerine

${ }^{59}$ Atalay, Fener Rum Patrikhanesi'nin Siyasi Faaliyetleri, s. 153.

${ }^{60}$ BOA, DH-ŞFR, 101/19-20.

${ }^{61}$ Atalay, Fener Rum Patrikhanesi'nin Siyasi Faaliyetleri, 154

${ }^{62}$ Kâzım Karabekir, İstiklal Harbimiz I, s. 68. Nitekim 15. Kolordunun etkili tedbirler alması sebebiyle Trabzon ve çevresine gönderilecek Rum çeteleri Batum'da Íngilizlerin desteğiyle Yunan subaylarınca eğitilip ondan sonra gönderilmeye başlandı. 
tecavüzde bulunulmuştu. ${ }^{63}$ Zaten; İstanbul Fener Rum Patrikhanesi, Karadeniz Bölgesi'ndeki metropolitler ve Rum cemiyetleri aralarında yaptıkları yazışmalarda Pontus Devleti'nin kurulması için iki hususun titizlikle uygulanmasına karar vermişlerdi: Bu hususlar:

1- Çeteciliğe fevkalade önem ve hız verilmesi

2- Asayişin ihlaline çalışılması ve daima Türkler ve Türk Hükümeti aleyhinde şikayetlerde bulunulması idi.

Fener Rum Patrikhanesi ve metropolitler, bunlar yapıldığı taktirde İtilaf Devletleri'nin özellikle İngiltere'nin Pontus davasına seyirci kalamayacaklarını düşünüyorlardı. Karadeniz'de asayişsizliğin var olduğu yönünde bir kanının İtilaf Yüksek Komiserleri ve Avrupa başkentlerini sarması durumunda İngiltere ve Yunanistan'ın bir askeri müdahaleye girişebileceği ve bu sayede Pontus Devleti'nin kurulabileceği öngörülüyordu. ${ }^{64} \mathrm{Bu}$ amaçla mütarekenin hemen akabinde Karadeniz'de büyük fakat gizli bir seferberlik başlatıldı. Bölgedeki Metropolitler ve çeteler, katliam yapmak için büyük çaba harcamaya başladılar. ${ }^{65}$

Patrikhane'nin metropolitlerin ve onların desteklediği Pontusçu çetelerin faaliyetlerine engel olmak için Milli Hükümet başlangıçta çeşitli tedbirler aldıysa da (İtilaf Devletleri temsilcilerine Pontus Rum iddialarının asılsız olduğu yönünde girişimde bulunmak, Rum çetelerini iknaya çalışmak ve kuvvet yoluyla bastırmak gibi) istenilen başarı sağlanamayınca, önce bu sorunu tamamen halletmek için Merkez Ordusu teşkil edildi daha sonra da Yunan donanmasının Karadeniz sahillerine çıkarma yapması ihtimaline karşı Karadeniz kıyıları savaş bölgesi ilan edildi. ${ }^{66^{3}}$

TBMM Hükümeti'nin bu kararı üzerine İstanbul Fener Rum Patrikhanesi, İtilaf Devletleri'ni harekete geçirdi. İtilaf Devletleri temsilcilerinin durumu protesto etmeleri ve yerli-yersiz müdahalede bulunmaları üzerine TBMM Hükümeti'nin Dışişleri Bakanı Yusuf Kemal Bey, ilgili devletlerin temsilcilerine Fener Rum Patrikhanesi'nin ve metropolitlerin iç yüzünü ortaya koyan bir nota gönderdi. Notada şöyle denilmekteydi:

"Mümessil efendilerin telgraflarında zikrolunan şikayet hakkında zirde vaziu'l imza Hariciye Nazırı, mülahazat-1 atiyye-i, nazar-1 dikkatlerine vaz'etmekle kesb-i şeref eyler:

Halen İstanbul Patrikhanesi'nin uzun zamandan beri Karadeniz sahillerinde merkezi Samsun olmak üzere bir Rum Hükümeti tesis etmek

\footnotetext{
${ }^{63}$ ATASE, ISH, K.98, G.49, B.49-1.

${ }^{64}$ BOA, DH-KMS, 49-2/42.

${ }^{65}$ ATASE, ÍSH, K.847, G.51, B.51-1.

${ }^{66}$ Nurettin Paşa Pontusçuları Anlatıyor, Yakın Tarihimiz II, s. 226.
} 
için çalışan Yunan Hükümeti ile birlikte hareket ettiği sabit olmaktadır. Bir çok hafi cemiyetler -ki bunların en mühimi 1904 yılında teessüs eden Pontus Cemiyeti'dir -senelerden beri bu gaye uğruna hasr-1 mesai etmişlerdir. Bu teşkilatın askeri ve adli tensikat ve tanzimata aid nizamnameleri, heykelleri, silahları, bayrakları, madalyaları ile cemiyetin mühr-i resmisi, geçen bahar zarfında kulüpleri dahilinde ele geçirildiğinden artık bu hususta şüpheye mahal kalmamıştır.

Esasen bu taharriyatın icrasını müteakip netice, Amerikan Fevkalâde Komiseri Amiral Bristol Cenablarına iblağ edilmiş idi. Binaen'aleyh geçen bahardan itibaren Büyük Millet Meclisi Hükümeti, cereyan eden vekayi hakkında ma'lûmât-1 kat'iyyeye malik bulunmaktadır. Hükümet burada da İzmir darbesinin tekrar olunmak istendiğine vakıf idi. Karadeniz Rumları her türlü kavaid-i insaniye ve hukuk haricinde teslih ve teşkilat altına alınarak, İzmir'de olduğu gibi son bir ihraç ameliyesine tevessül hususunda onların muavenetine mahzar olmak ve bu suretle ekseriyeti teşkil eden Müslümanları, Rum ve ekalliyetlerin idaresi altına vaz' etmek, ba'dehu hiçbir mütala'aya tesadüf etmeden memlekete tesahüb için bu Müslüman ekseriyeti muntazam surette imha etmek tasavvurunda bulunulduğundan bihaber değildi.

İşte bervechi bâlâ zikr olunan taharriyattan evvel Yunan muhiblerinin Karadeniz sahilindeki Türk arazisi hakkındaki projeleri, Mondros Mütarekesi akabinde bütün vüs'atiyle tazelenmiştir.

Hükümetin muhat bulunduğu müşkil vaz'iyetinden istifade eden Samsun Metropoliti, Karadeniz sahilindeki Türk arazisine Rusya'dan ve Anadolu içlerinden getirilerek yerleştirilecek Rumlarla ve bu suretle o havalide ekalliyetlerin miktarını teksir ve teksif edecek mesai ile meşgul olmak üzere bir komisyon teşkil etmişti. Bundan ma'ada mühim ve külliyetli miktarda silah ve cephane memleket dahiline sevk olunarak Rumlara tevzi edilmekte ve diğer taraftan çeteler teşkilatı kemâl-i germi ile devam etmekte idi.

İzmir su-i kasd'ının getirdiği hareket-i milliye ve müdafaa-i meşrua'a üzerine Yunanlılar bütün kuvvetlerini mezkûr havalide tahşid etmek mecburiyetinde kaldıklarından, Karadeniz sahilinde tasavvur ettikleri proje hız-1 husule gelemedi. Fakat son zamanlara kadar hâlâ mevcud olmakta devam eden ve ilk zamanlar mükemmelen teslih ve tensik edilmiş olan Rum çeteleri, bütün bu harekât-1 tecavüzkârâneye karşı hiçbir silah ve teşkilata malik olmayan Müslümanlar hakkında irtikâb ettikleri mezalim ve itisafat ile hükümetin nazar-1 dikkatini celbden hâlî kalmadılar." ${ }^{67}$

Görüldügüü üzere Rum din adamları Rum halkına yalnızca siyasi telkinlerde bulunmakla kalmayıp, çete faaliyetlerini ve Rum göçlerini de faal

\footnotetext{
${ }^{67}$ Pontus Meselesi, V. Kısım, 7-8.
} 
bir şekilde desteklemişler, kiliseleri birer göçmen bürosu ve silah deposu haline getirmişlerdir. Sonradan Pontus çetelerini bastırmak görevi ile Merkez Ordusu'nun başına getirilen Nurettin Paşa, metropolitlerin faaliyetleri ile ilgili olarak hatıralarında şunları söylemektedir.

"En önemlisi ise yurdumuzun içinde kurulmuş ve işleyen bütün bu düşmanca tahrik ve teşkilatı, insanlara dostluk ve barış tavsiye edip, kardeşçe yaşama yolları göstermeleri gereken din adamlarının yani metropolitlerin, papazların idare etmekte olduklarıdır. Papazların din kisvesi altında ne kanlı faciaların amili ve teşvikçisi olduklarını ispat edecek yüzlerce, binlerce vesika elde etmiş bulunuyoruz..."

${ }^{68}$ Nurettin Paşa Pontusçuları Anlatıyor, Yakın Tarihimiz II, s. 225. 